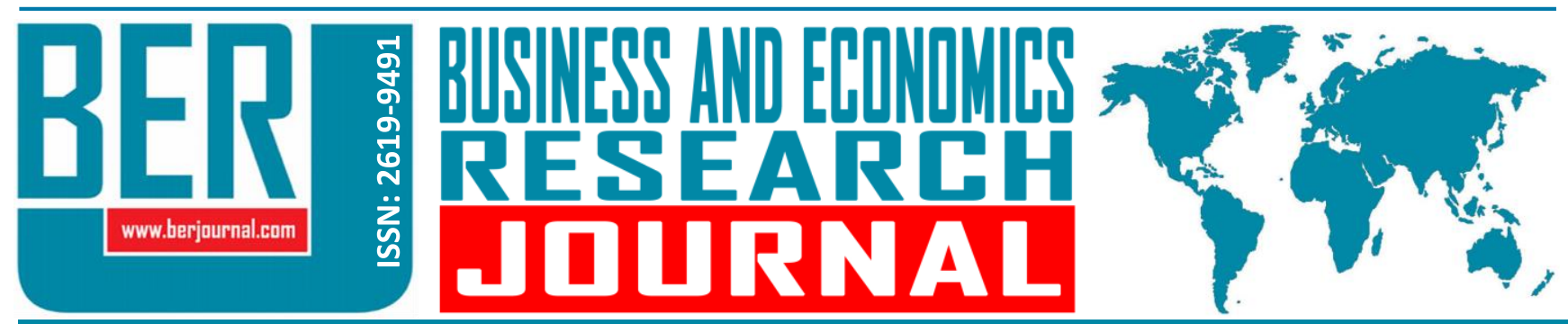

Business and Economics Research Journal Vol. 11, No. 3, 2020, pp. 855-873 doi: 10.20409/berj.2020.286

\section{Duygusal Emek Davranışlarının Tükenmişlik Sendromu ve İșten Ayrılma Niyeti Üzerindeki Etkisi: Hazır Giyim Sektöründe Bir Araştırma}

\author{
Derya Keles ${ }^{\mathrm{a}}$, Esra Aydin Goktepe $^{\mathrm{b}}$
}

Öz: Hazır giyim sektöründe çalışanlardan, müşteri memnuniyeti sağlamak için yoğun şekilde duygusal emek sarf etmeleri beklenmektedir. Bu çalışmada, hazır giyim sektörü içerisinde çalışan satış görevlilerinin duygusal emek davranışlarının tükenmişlik sendromu ve işten ayrılma niyeti üzerindeki etkileri araştırılmıştır. Bu çalışmanın örneklemini dört farklı hazır giyim markasının istanbul'daki dört farklı ilçesinde (Şişli, Bakırköy, Beylikdüzü, Bayrampaşa) cadde üstü ve alışveriş merkezi mağazalarında çalışan satış görevlileri oluşturmaktadır. Araştırma yöntemi nicel araştırma olarak belirlenmiş ve araştırmaya 296 satış görevlisi katılmıştır. Araştırma sonucunda, duygusal emek davranışlarının yüzeysel davranış ve samimi davranış boyutlarının, çalışanların tükenmişlik sendromunu ve işten ayrılma niyetini artırdığı belirlenmiştir. Ayrıca, derinlemesine davranış boyutunun, tükenmişlik sendromu ve işten ayrılma niyeti ile anlamlı ilişkisi olmadığı belirlenmiştir.

\section{The Effect of Emotional Labor Behaviors of Employees on Burnout Syndrome and Intention to Quit: A Research in the Ready-made Clothing Sector}

Abstract: Employees in the service sector are expected to make intensive emotional labor behaviors to ensure customer satisfaction. In this study, the effects of service sector salespeople's emotional labor behaviors on burnout syndrome and intention to quit were investigated. The sample of this study is the salespeople working in street stores or shopping malls stores in four different districts (Sisli, Bakırkoy, Beylikduzu, Bayrampasa) of four different ready-made clothing brands in Istanbul. The research methodology was determined as quantitative research and 296 salespeople participated in the research. As a result of the research, it was determined that the surface acting and close behavior dimensions of emotional labor behaviors increased the burnout syndrome and intention to quit. In addition, the in-depth behavior dimension was not significantly associated with burnout syndrome and intention to quit.
Anahtar Sözcükler: Duygusal Emek Davranışı, Tükenmişlik Sendromu, işten Ayrılma Niyeti

JEL: M12, M54

$\begin{array}{ll}\text { Geliş } & : 23 \text { Mart } 2020 \\ \text { Düzeltme } & : 18 \text { Mayıs } 2020 \\ \text { Kabul } & : 11 \text { Haziran } 2020 \\ \text { Tür } & : \text { Araştırma }\end{array}$

Keywords: Emotional Labor Behavior, Burnout, Intention to Quit

JEL: M12, M54

$\begin{array}{ll}\text { Received } & : 23 \text { March } 2020 \\ \text { Revised } & : 18 \text { May } 2020 \\ \text { Accepted } & : \text { 11 June } 2020 \\ \text { Type } & : \text { Research }\end{array}$

Master Student, Istanbul Arel University, Istanbul, Turkiye, deryakeles37@gmail.com (ORCID ID: 0000-0001-8152-5420)

b Asst. Prof., PhD., Istanbul Arel University, Faculty of Economics and Administrative Sciences, Departman of Business Administration, Istanbul, Turkiye, esraaydingoktepe@arel.edu.tr (ORCID ID: 0000-0001-7833-448X) 


\section{Giriş}

Hizmet sektöründe satış ve pazarlama üzerine ticaret yapan işletmeler, gelirlerini arttırabilmek ve kâr elde edebilmek amacıyla rekabet avantajı elde etmek istemektedirler. Bu amaçla yola çıkan işletmeler var olan müşteriyi elde tutmak, yeni müşteriler kazanmak ve hedeflerini gerçekleştirebilmek için işletmeyi başarılı bir şekilde temsil edecek satış görevlilerine intiyaç duyarlar. İşletmeler için yetenekli çalışanın elde tutulması önemli olmasına rağmen rekabetin çok yoğun olarak yaşandığı perakendecilik sektörü, personel devir oranının yüksek olduğu sektörlerden biridir. Sektörel bazda personel devir oranlarının araştırıldığı PERYÖN Çalışan Devir Oranı Raporu (2019), inşaat sektöründen sonra personel devir oranının en yüksek olduğu sektörün perakendecilik olduğunu göstermektedir. Hizmet sektöründe, çalışan davranışlarının kontrol edilmesinin, müşteriyi memnun edeceği düşünüldüğünden, çalışanların davranışlarını ve duygularını müşteriyi memnun edecek şekilde göstermeleri beklenmektedir.

Duygusal emek, çalışanların müşterilerle olan ilişkilerinde önemli bir kavramdır. İşletmelerin çalışana uygulamış olduğu kontrol ve müdahale etme güdüsü zamanla çalışanlar üzerinde bir baskı unsuru olarak kendini göstermektedir. Düşüncelerinin ve davranışlarının kontrol edilmesi ve müşterilere karşı davranışlarının bastırılması sonucunda, çalışanların zamanla yaptıkları işe duydukları memnuniyetsizlik artmakta ve çalışan işten ayrılmayı düşünmeye başlamaktadır. Verilen hizmetin kalitesinin ve müşteri memnuniyetinin önemli olduğu perakendecilik sektöründe, çalışanların duygusal emek davranışlarının, tükenmişlik sendromu ve işten ayrılma niyeti üzerindeki etkisini ortaya koymak bu çalışmanın amacını oluşturmaktadır. Araştırma değişkenlerinin en çok incelenmiş olduğu eğitim, sağlık ve turizm gibi sektörlerde bu alanda yapılan çalışmaların sayısının oldukça fazla olmasına rağmen satış görevlileri üzerinde yapılan çalışmaların sayısı azdır. Bu çalışma Türkiye'de perakendecilik sektöründe faaliyet gösteren farklı hazır giyim markaların satış görevlilerinin duygusal emek davranışlarının, tükenmişlik sendromu ve işten ayrılma niyetleri üzerindeki etkisini belirlemek için yapılan az sayıdaki çalışmadan biri olması açısından önemlidir. Perakendecilik sektöründe personel devir oranın yüksek olması ve bu oranın düşürülmesi için duygusal emek ve tükenmişlik sendromu bağlamında öneriler sunmayı hedeflemesi de çalışmanın alan katkılarından biridir. Ayrıca literatürde yer alan benzer çalışmaların sonuçları için kıyaslama sağlayacak veri sunması ve Türkiye ölçeğinde araştırma konusunun genelleştirilebilmesi için veri sağlaması da bu araştırmanın katkıları arasında gösterilebilir.

Çalışmada öncelikle, kavramsal çerçeve ve metodoloji verildikten sonra hipotez sonuçlarından hareketle çalışmanın literatüre katkısı değerlendirilerek araştırma bulguları yorumlanmıştır.

\section{Literatür Taraması}

\subsection{Kavramsal Çerçeve}

Araştırma modelinin oluşturulmasında, ampirik çalışma ve sonuçlarının yorumlanmasında kullanıldı̆̆ı için çalışmanın bu bölümünde, araştırma değişkeni olan duygusal emek davranışına, tükenmişlik sendromuna ve işten ayrılma niyetine yönelik literatürde yer alan kavramsal analizlere ve teorik altyapıya değinilmiştir. Ayrıca bu bölümde araştırma değişkenleri arasındaki ilişkiler ve hipotez geliştirme sürecinden bahsedilmiştir.

“Duygu"yu tanımlamak, duygusal emek kavramının anlaşımasına katkı sağlayacağı için öncelikle duygu kavramına değinilecektir. Descartes duyguyu, kişinin etki altında kaldığı etmenlerin bilinmemesi ile ortaya çıkan algılar olarak ifade etmiştir (Yatkın, 2007). Descartes'e göre duygular, kişilerin fikirleriyle şekillenmektedir (Akçay ve Çoruk, 2012). Duygu kavramını temel alan duygusal emek kavramı, "gözlemlenebilecek tavır ve davranışlar ortaya çıkarmak için duygulara hakim olunması" şeklinde tanımlanmıştır. Duygusal emek kavramının ele alındığı ilk çalışmalar, havayolu çalışanları üzerinde gerçekleştirilmiştir. Bu çalışmalarda duygusal emek, gözlemlenebilecek tavır ve davranışlar ortaya çıkarmak için duygulara hakim olunması, duyguların yönetimi olarak belirtilmiş ve bir ücret karşıllı̆ında sergilendiği vurgulanmıştır (Hochschild, 1983). Ashforth ve Humphrey (1993), duygusal emeği, çalışanın duruma uygun davranışı sergilemesi, Morris ve Feldman (1996) ise işletmenin beklediği duyguları davranışlarla 
gösterebilmek için çalışanın sarf ettiği çaba olarak tanımlamışlardır. Duygusal emek teorilerine katkı sağlayan Grandey (2000), duygusal emeği, çalışma ortamlarında gerçekleşen duygu düzenlemesi olarak tanımlamıştır.

Çalışan bireyin duygusal emek sarf ederken iki araçtan birini (yüzeysel davranış ve derinlemesine davranış) kullandığını belirten Hochschild'dan (1983) sonra, Ashforth ve Humprey (1993) bu iki araca ek olarak samimi davranış boyutunu da literatüre kazandırmıştır. Yüzeysel davranış (surface acting); çalışanın, işletmenin kendisinden beklediği davranışları belirli vücut hareketleri ile gösterebilmek için gerçek hislerini yönetme çabasıdır. Yüzeysel davranış sergileyen bireyin, duygularında herhangi bir değişiklik olmamakla birlikte bireyler yalnızca tavır ve davranışlarını değiştirmektedirler. Çalışanın yüzeysel davranışı, yani gerçek duygularını bastırma eylemini, işini korumak adına işletmenin kurallarına uygun olarak yapmasıdır (Oral ve Köse, 2011). İ̧̧in gerektirdiği duyguları göstermeye çalışan bireyin yaptığı aslında roldür. Gerçek duyguları bastırmaya çalışma, işletmenin istediği şekilde müşteriye davranış şekillerini ayarlamaya çalışma, bu çalışma esnasında ekstra harcanan bir çabayı gerektirmektedir. Çalışanın gerçekte hissettiği duygularla sergilediği davranışların birbiriyle çelişmesi zamanla çalışanda işletmeye ve işine karşı bir yabancılaşma hissetmesine neden olabilmektedir (Üzümcü ve Şahin, 2017). Yüzeysel davranış, duyguları değiştirmek yerine sadece değişen duygu gösterimine odaklandığı için yetersizlik, otantik olamama, duyarsızlaşma, duygusal tükenme, memnuniyetsizlik gibi olumsuz sonuçlar gelişmesine neden olmaktadır (Brotheridge ve Lee, 2002). Derinlemesine davranış (in-depth behavior) sergileyen çalışan, işletmenin kendisinden istediği davranışı bizzat hissetmeye çalışmaktadır (Asfhort ve Humprey, 1993). Burada çalışanın kendi çabası da devreye girmekte, çalışan aslında müşteriye karşı empati duygusunu geliştirme çabası içine girmekte, bu şekilde de kendi duygularına ve davranışlarına yön vermektedir (Rupp, Mccance, Spencer ve Sonntag, 2008). Çalışanın bu davranışı, aslında bir tiyatro oyuncusunun anılarını ve hayallerini düşünerek davranışlarını şekillendirip, seyirciyi etkilemeye çalışması gibi görülmektedir (Eroğlu, 2014). Derinlemesine davranış, başkasının duygularını anlamaya ve kendi duygularını değiştirmeye odaklandığı için, yeterlilik duygusu, otantik olma, iş doyumu ve performansının artışı gibi olumlu sonuçlar gelişmesine neden olmaktadır. Samimi davranış (close behavior); çalışanın gerçekten hissettiği duygularıyla işletmenin kendisinden sergilemesini istediği duyguların çelişmemesi aksine aynı olması durumunda ortaya çıkan davranış şeklidir (Köksel, 2009). Samimi davranışta birey, işletmenin beklediği davranışları zaten var olan duygularını yansıtarak sergilemektedir. Bir satış görevlisinin yorgun olmasına rağmen müşterisine karşı hissettiği pozitif duygular nedeniyle her gelişinde onu güler yüzle karşılaması samimi duygusal emek davranışıdır. Burada, çalışan işletmenin kendisinden beklediği davranışları gösterirken, kendi samimi duygularını da müşteriye aktararak samimi davranış sergilemektedir. Çalışanın işletmeye olan sevgisi ve bağılıı̆ı işletmenin koyduğu kurallarla özdeşleştiğinde, çalışan içinden geldiği gibi yani doğal davranmakta ve bu durum aynı zamanda duygusal emeğin olumsuz etkilerini de azaltmaktadır (Diefendorf ve Gosserand, 2003). Çünkü bireyin bir işi severek, samimi duygularla yapması durumunda o işin gerektirdiği tüm kuralları isteyerek yerine getirmesi ve duygusal emek gösteriminde yaşadığı olumsuz durumların da en aza inmesi beklenmektedir. Samimi davranış sergileyen çalışanların, iş eylemlerini gerçekleştirirken yansıtmaları beklenen duyguları gerçekten hissediyor olmaları, yeterlilik duygusu, otantik olma, iş doyumu ve performansın artması gibi olumlu sonuçlara neden olmaktadır (Brotheridge ve Grandey, 2002; Grandey, Fisk ve Matilla, 2005).

Günümüzde giderek çoğalan ve neredeyse sürekli yaşanan bir kavram olan tükenmişlik (burnout) literatüre, 1974 yılında stresle ilgili yapılan araştırmalar sonucunda dahil olmuştur. Tükenmişlik sendromu kavramı, bireyin iyi oluş halinin bozulması, içsel motivasyon kaynaklarının, enerjisinin azalması, yıpranması ve iş doyumunun azalması olarak tanımlanmıştır (Freudenberger, 1974: 159; Dworkin, Saha ve Hill, 2003: 110; Schepman ve Zorate, 2008: 437). Bir başka tanımda ise tükenmişlik sendromu, çalışan bireyin, çalışma ortamının getirdiği bireysel ve örgütsel faktörlerin etkisiyle, yüz yüze iletişimde olmanın sonucunda fiziksel ve mental olarak etkilenmesi, bireyin sahip olduğu enerjinin üstünde enerji harcaması ile yaşadığı yıpranma olarak belirtilmiştir (Maslach ve Zimbardo, 1982). Tükenmişlik, üç boyutlu bir sendromdur (Maslach ve Zimbardo, 1982: 3; Wright ve Douglas, 1997; Maslach, Schaufeli ve Leiter, 2001: 399).

Duygusal tükenme, tükenmişlik sendromu kavramının en temel boyutudur (Sürgevil, 2005). Duygusal tükenme, aşırı iş yükü nedeniyle duygusal ve fiziksel kaynaklarının azalması ile başlayan tükenmişlik sendromunun ilk basamağıdır (Wright ve Douglas, 1997: 492; Maslach vd., 2001: 402). Duygusal tükenme 
halindeki bireyler, çevresindeki insanlarla olan iletişiminde geçmişte olduğu gibi iyi iletişimlerinin olmadığını düşünmekte ve kendilerini mutsuz, gergin hissetmektedirler (Leiter ve Maslach, 1988). Aslında duygusal tükenme stresle ortaya çıkan ilk tepkidir ve bu tepki sonucunda bireyler, kendilerini yetersiz ve gergin hissetmektedirler. Bireylerin hissetmeye başladığı bu olumsuz düşünceler, bireylerin işletme için zararlı sonuçlar doğurabilecek davranışlar sergilemesine neden olmaktadır. Bu sonuçların en önemlisi, işe gitme isteksizliğidir (Maslach, 2003). Tükenmişliğin ikinci boyutu olan duyarsızlaşma, bireylerin çevresi ile kurduğu ilişkinin bozulmasıdır. Duyarsızlaşma boyutunda bireyler, çevresine karşı olumsuz ruh haline sahip olmakta, alaycı tutum ve duygular geliştirmektedirler (Wright ve Douglas, 1997: 492; Maslach vd., 2001: 403). Duyarsızlaşma, duygusal tükenmenin sonunda yaşanan bir süreçtir. Bu süreçte, bireyler çalıştığı kişilere ve müşterilerine karşı olumsuz davranışlar sergilemekte ve işlerine karşı duyarsızlaşmaktadırlar (Torun, 1997). Duyarsızlaşma sürecinde bireyler, birlikte çalıştığı kişilere, yöneticilerine, müşterilere ve hatta bağı bulunduğu işletmeye karşı olumsuz ve çevresine karşı alaycı bir tutum içinde olmaktadırlar (Maslach ve Jackson, 1981). Tükenmişliğin üçüncü ve son boyutu olan kişisel başarı hissinin azalmasında birey öz değerlendirmede bulunmaktadır. Tükenmişliğin bu boyutunu yaşayan bireyler, kendilerini negatif değerlendirmekte ve kendilerini düşük performans sergileyen başarısız bireyler olarak görmektedirler (Maslach ve Zimbardo, 1982: 5; Wright ve Douglas, 1997: 492; Maslach vd., 2001: 403). Tükenmişliğin son boyutunda, bireyler yaptıkları işte kendilerini yetersiz ve başarısız olarak değerlendirmekte ve yaptıkları işin verimli olmadığına inanmaktadırlar (Maslach vd., 2001). Kişisel başarı hissi azalan bireyler, çevrelerine yansıttığı olumsuzluklar nedeniyle çevresinden olumsuz geri bildirimler almaktadırlar. Bu geri bildirimler sonunda, bireyler kendilerini ve yaptıkları işleri sorgulamaktadırlar. Bu sorgulama sonunda, kendini yetersiz hissetme ve motivasyon kaybı yaşanmaktadır (Ersoy ve Utku, 2005).

Tükenmişlik sendromu, işten ayrılma niyetini artıran ve zemin hazırlayan en önemli faktörlerden biridir. Tükenmişliğin psikolojik belirtisi olarak bireyin işi bırakma eğiliminde olması ve sık sık işe gitmek istememesi işletmenin performansında düşüş yaşanmasına neden olmaktadır (Maslach ve Jackson, 1981; Perlman ve Hartman, 1982; Potter, 1998). İşten ayrılma niyeti, işletmeler için personel maliyetlerini artıran önemli bir örgütsel değişkendir. İşten ayrılmalar sonrası, yeni personelin işe alınması sürecindeki katlanılan maliyetlerin azaltılması için işten ayrılma niyetinin nedenlerinin belirlenmesi gerekmektedir (Aydın Göktepe ve Keleş, 2019: 266). İşten ayrılma niyeti, bir işletmede çalışan personelin memnuniyetsiz olduğu durumlara karşı sessiz kalması ve bu sessizliğin, onu yeni iş arayışlarına yönlendirmesi olarak açıklanmaktadır (Tak ve Çiftçioğlu, 2008). Çalışan, bu süreçte yeni bir iş arayışına girdiği gibi örgüt içinde de verimliliğini kaybetmektedir (Griffeth, Hom ve Gaertner, 2000). Çalışanın işten ayrılması, işletmeye beraberinde birtakım sorunlar da getirmektedir. Çalışanın iş̧en ayrılma kararını vermesi, işletmenin deneyimli çalışanı kaybetmesi ve onun yerine gelecek çalışanı eğitmek ve geliştirmek gibi bir takım maliyetlere katlanması anlamına gelmektedir (Yang, 2008). İşten ayrılma niyeti işin anlamlı bulunması, yönetici ve çalışma arkadaşları ile kurulan iyi ilişkiler, adil ücretlendirme sistemleri gibi unsurlar ile azalabilmektedir (Waldroop ve Butler, 2011).

Işten ayrılma niyetinin, işletme için maliyet artırıcı sonucu personel devridir. Bir işletmede personelin sürekli olarak değişmesi işletme için olumsuz sonuçlara neden olabilmektedir. Bu sonuçlar şöyle sıralanabilir:

- İşten ayrılmaya niyetlenen ya da karar veren bireyin işletme içinde performansında düşme görülmektedir.

- Çalışan, işten ayrılma sürecinde, içinde bulunduğu olumsuz havayı çalışma arkadaşlarına da yansıtmakta ve onların performansını da negatif olarak etkilemektedir.

- İşletme, işten ayrılan çalışanın yerine alınacak personel için ayrıca zaman harcamaktadır.

- İşletme, işe alınacak yeni personele verilecek çeşitli eğitim masrafları için bir bütçe oluşturmak zorunda kalmaktadır.

- İşe yeni alınan çalışanın, adaptasyon süresince işletmenin verimliliği düşük olacaktır.

- İşletme tecrübeli personeli kaybetmiş olacaktır. 


\subsection{Duygusal Emek ve Tükenmişlik Sendromu Arasındaki iliş̧ki}

Duygusal emek ağırlıklı işlerde çalışanların, tükenmişlik düzeylerinin yüksek olduğu birçok araştırmada tespit edilmiştir (Kruml ve Geddes, 2000; Montgomery, Panagopolou, De Wildt ve Meenks, 2006, Kaya ve Özhan, 2012).

Wharton (1993), duygusal emek ağırlıklı olan ve duygusal emek içermeyen farklı meslek grupları üzerinde araştırmalar yapmıştır. Çalışma sonunda duygusal emek yoğunluğu farklı olan bu meslek gruplarının, tükenmişlik düzeylerinin benzer olduğu tespit edilmiştir. Bu durumda tükenmişlik sendromu, duygusal emek ile bağdaştırılmamış, duygusal emek gösterilmeyen mesleklerde de tükenmişlik sendromunun görülebileceği belirtilmiştir. Grandey (1999) ise araştırmasında duygusal emek ve tükenmişlik sendromu arasında anlamlı bir ilişki olduğunu tespit etmiştir.

Duygusal emeğin yoğun olduğu meslek gruplarından biri olan hekimler ile gerçekleştirilen araştırma sonucunda, duygusal emeğin yüzeysel davranış boyutunun, duygusal tükenmeyi ve duyarsızlaşmayı arttırdığı, duygusal emeğin derinlemesine davranış boyutu ile tükenmişlik sendromu arasında anlamlı bir ilişkinin olmadığı tespit edilmiştir (Oral ve Köse, 2011).

Chu (2002), turizm sektöründe gerçekleştirdiği çalışmasının sonucunda, otel çalışanlarının derinlemesine davranış boyutu ile duygusal tükenme düzeyi arasında negatif yönlü ilişki olduğu sonucuna ulaşmıştır. Bu durum gösteriyor ki çalışanların derinlemesine davranışları arttıkça tükenmişlik düzeyleri azalacaktır.

İ̧s-aile çatışması, duygusal emek ve tükenmişlik düzeyi ilişkisini belirlemek için Alman kamu işletmeleri çalışanları ile gerçekleştirilen çalışma sonucunda, yüzeysel davranış ve tükenmişlik sendromu arasında anlamlı ve pozitif yönde ilişki bulunmuş ve duygusal emek davranışlarının tükenmişlik sendromu üzerindeki ilişkisinde iş-aile çatışmasının aracılık etkisi olduğu belirlenmiştir (Montgomery vd., 2006).

Duygusal emeğin, iş doyumunu ve tükenmişlik sendromu üzerindeki etkisini belirlemek için, Çinli akademik personeller ile gerçekleştirilen çalışma sonucunda, yüzeysel davranışın, iş doyumunu ve tükenmişlik sendromu üzerindeki etkisinin negatif olduğu belirlenmiştir. Derinlemesine davranışın ise iş doyumunu ve tükenmişlik sendromu üzerinde pozitif etkileri olduğu belirlenmiştir. Aynı çalışmada, Çinli akademisyenlerin, derinlemesine davranış gösterimlerinin diğer duygusal emek boyutlarına kıyasla daha yüksek düzeyde olduğu da belirtilmiştir (Zhang ve Zhu, 2007).

Kaya ve Özhan (2012), çalışmalarında samimi davranış boyutunun duyarsızlaşma üzerinde negatif, kişisel başarı hissinin azalması üzerinde pozitif etkisi olduğunu belirtmişlerdir. Bir başka çalışmada ise, duygusal tükenme davranışının samimi davranış boyutunun, tükenmişlik sendromunun, duyarsızlaşma üzerinde negatif, kişisel başarı hissinde azalma boyutu üzerinde pozitif etkisi olduğu belirlenmiştir (Çelik, Tabak, Uysal, Sıgrı ve Turunç, 2011).

Literatürdeki duygusal emek ve tükenmişlik sendromu ilişkisini belirlemeye yönelik gerçekleştirilen çalışmaların incelenmesinin ardından, duygusal emek davranışlarından samimi davranış boyutu ve tükenmişlik sendromu ile ilgili az sayıda çalışma olması göz önünde bulundurularak (Çelik vd., 2011; Kaya ve Özhan, 2012), bu çalışmada duygusal emeğin tükenmişlik sendromu üzerindeki etkisini belirlemek amacıyla aşağıdaki hipotezler oluşturulmuştur;

H1a: Hazır giyim sektöründe çalışanların yüzeysel davranışlarının, tükenmişlik sendromu üzerinde pozitif yönde bir etkisi vardır.

H1b: Hazır giyim sektöründe çalışanların samimi davranışlarının, tükenmişlik sendromu üzerinde pozitif yönde bir etkisi vardır.

H1c: Hazır giyim sektöründe çalışanların derinlemesine davranışlarının, tükenmişlik sendromu üzerinde negatif yönde bir etkisi vardır. 


\subsection{Duygusal Emek Davranışı ile İşten Ayrılma Niyeti Arasındaki ilişki}

Hizmet sektöründe faaliyet gösteren birçok çalışma alanında olduğu gibi perakendecilik alanında da müşteri odaklı çalışma söz konusudur. Çalışanlar müşterilere gerek fiziksel gerekse duygusal olarak hizmet ederler. Fiziksel çabanın yanı sıra çalışanın göstermiş olduğu duygusal emek davranışının yoğun olduğu işlerde, tükenmişlik sendromu yaşayan çalışan kendini daha iyi hissedebilmek için başka iş arayışlarına girmeye başlar. Literatürde bu konu hakkında yapılan araştırmalara rastlamak mümkündür.

İzmir ilinde faaliyet gösteren bir otelin çalışanları ile gerçekleştirilen araştırmada, yüzeysel davranış ile duygusal tükenme arasında anlamlı ve pozitif ilişki olduğu ve duygusal tükenmenin de işten ayrıma niyetini arttırdığı belirlenmiştir (Korkmaz, Sünnetçioğlu ve Koyuncu, 2015).

Kahramanmaraş'ta belediye çalışanları ile gerçekleştirilen bir araştırmada yüzeysel davranış ve işten ayrılma niyeti arasında pozitif anlamlı bir ilişkinin olduğu belirlenmiştir (Yeşil ve Mavi, 2018).

Derinlemesine davranışın, işten ayrılma niyetini azalttığını gösteren çalışmalar da bulunmaktadır. Bu sonuç, bireylerin başarı hissi yaşamaları nedeniyle olumlu duygular içinde olmaları ile açıklanmaktadır (Brotheridge ve Grandey, 2002; Kaya ve Özhan, 2012; Korkmaz vd., 2015). Derinlemesine davranış gösteren çalışanlar, yöneticileri tarafından tercih edilen çalışan olmaları nedeniyle yöneticileri ile iyi ilişkiler kurmakta, bu nedenle de işlerini bırakmayı düşünmemektedirler (Ünlü ve Yürür, 2011).

Duygusal emek davranışını ele alan çalışmalarda, genellikle duygusal emek davranışı, derinlemesine davranış ve yüzeysel davranış boyutları ile ele alınmaktadır. Bu nedenle samimi davranış boyutu ile ilgili az sayıda çalışma bulunmakta, bu çalışmalarda da samimi davranışın örgütsel vatandaşlık davranışı ile ilişkisi (Bıyık ve Aydoğan, 2014), tükenmişlik sendromu ile ilişkisi (Çelik vd., 2011; Kaya ve Özhan, 2012), işe bağlılık ve yönetici desteği ile ilişkisi (Gülova, Palamutçuoğlu ve Palamutçuoğlu, 2013), demografik faktörlerle ilişkisi (Çoruk, 2014) ele alınmış, işten ayrılma niyeti üzerindeki etkisi ele alınmamıştır.

Literatürde yapılan araştırmalara dayanarak, bu çalışmada duygusal emeğin işten ayrılma niyeti üzerine etkisini belirlemek amacıyla aşağıdaki hipotezler oluşturulmuştur.

H2a: Hazır giyim sektöründe çalışanların yüzeysel davranışlarının, işten ayrılma niyeti üzerinde pozitif yönde bir etkisi vardır.

H2b: Hazır giyim sektöründe çalışanların samimi davranışlarının, işten ayrılma niyeti üzerinde pozitif yönde bir etkisi vardır.

H2c: Hazır giyim sektöründe çalışanların derinlemesine davranışlarının, işten ayrılma niyeti üzerinde negatif yönde bir etkisi vardır.

\section{Metodoloji}

Araştırmanın kavramsal kapsamı, duygusal emek, tükenmişlik sendromu ve işten ayrılma niyeti kavramlarından oluşmaktadır. Bu bağlamda duygusal emek, tükenmişlik sendromu ve işten ayrılma niyeti değişkenleri arasındaki ilişkiler incelenerek, çalışma bulgularından hareketle, işletme yöneticilerine ve çalışanlara önerilerde bulunmak amaçlanmaktadır.

Bu bölümde, araştırmanın metodolojisi, araştırma verilerinin analizleri ve elde edilen bulguların yorumları verilmiştir.

\subsection{Araştırmanın Örneklemi}

Bu çalışmanın evrenini, dört farklı hazır giyim markasının, İstanbul'daki dört farkıı ilçesindeki (Şişli, Bakırköy, Beylikdüzü ve Bayrampaşa) satış görevlileri oluşturmaktadır. Illçe seçiminde belirleyici kriter, satış görevlisi sayısının yoğunluğudur. 2019 yılında söz konusu markaların Şişli, Bakırköy, Beylikdüzü, Bayrampaşa ilçelerindeki cadde üstü ve alışveriş merkezi mağaza sayısının toplam 15 olduğu ve bu mağazalarda 800 satış görevlisinin çalıştığı belirlenmiştir. Araştırma örneklemi belirlenirken, basit rastgele örnekleme yöntemi 
kullanılmıştır. Sayısı belli olan örneklem formülü kullanılmış (Ural ve Kılıç, 2013) ve örneklem büyüklüğü 260 olarak hesaplanmıştır. Veriler Ocak-Nisan 2019 tarih aralığında toplanmış ve geçerli 296 ankete ulaşılmıştır.

\subsection{Araştırmada Kullanılan Ölçekler}

Araştırmada nicel araştırma yöntemi benimsenmiştir. Araştırma veri toplama amacıyla oluşturulan anket formu dört bölümden oluşmaktadır. Birinci bölüm katılımcıların demografik bilgileriyle ilgili sorulardan oluşmaktadır. Bu sorular katılımcıların cinsiyeti, yaşı, medeni durumu, eğitim seviyesi ve mesleki deneyimlerinden oluşmaktadır. Araştırmada kullanılan ölçekler toplamda üç adet olup, 5’li Likert şeklinde düzenlenmiştir. Soru formu "Tamamen Katılıyorum", "Katılıyorum", "Kararsızım", "Katılmıyorum" ve "Hiç Katılmıyorum" şeklinde derecelendirilmiştir. (1=Hiç Katılmıyorum, 5= Tamamen Katılıyorum).

Araştırmanın ikinci bölümünde duygusal emek ölçeğinin oluşturduğu ifadelerin yer aldığı maddeler bulunmaktadır. Diefendorff, Croyle ve Gosserand (2005) tarafından geliştirilen Duygusal Emek Ölçeği 13 madde içermektedir. Duygusal Emek Ölçeği, Basım ve Beğenirbaş tarafından 2012 yılında Türkçeye uyarlanmıştır. Ölçek üç alt boyuttan oluşmaktadır.

Araştırmanın üçüncü bölümünde tükenmişlik sendromu ölçeğinin oluşturduğu ifadelerin yer aldığı maddeler bulunmaktadır. Tükenmişlik Sendromu Ölçeği; Maslach ve Jackson (1981) tarafından geliştirilmiş ve 22 madde içermektedir. Tükenmişlik sendromu Ölçeği, Ergin (1992) tarafından Türkçeye uyarlanmıştır. Ölçek üç alt boyuttan oluşmaktadır.

Araştırmanın dördüncü bölümünde ise işten ayrılma niyeti ölçeğinin oluşturduğu ifadelerinin yer aldığı maddeler bulunmaktadır. İşten Ayrılma Niyeti Ölçeği; Wayne, Shoreve Liden (1997) tarafından geliştirilmiş olup, üç madde içermektedir. İşten Ayrılma Niyeti Ölçeği Küçükusta tarafından 2007 yılında Türkçeye uyarlanmıştır. Ölçeğin alt boyutu bulunmamaktadır.

\subsection{Araştırma Modeli}

Araştırma modeli, duygusal emek davranışının ve alt boyutlarının çalışanın tükenmişlik sendromu ve işten ayrılma niyetine etkisini belirlemeye yönelik planlanmıştır. Araştırma modeli Şekil 1'de verilmiştir.

Şekil 1. Araştırma Modeli

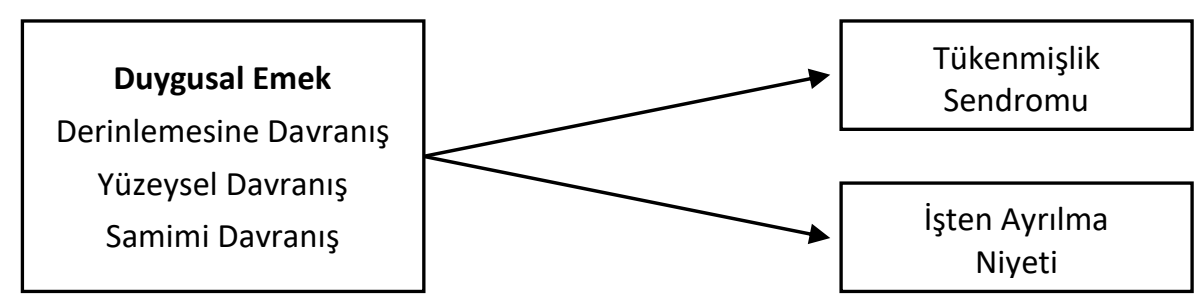

\subsection{Verilerin Analizi}

SPSS 22.0 programına anketlerden elde edilen veriler girilmiş ve bu çerçevede verilerin yorumlanabilmesi için gerekli olan istatistiksel analizler gerçekleştirilmiştir.

\subsubsection{Demografik Değişkenler}

Araştırmaya katılan satış görevlilerinin, demografik özelliklerini belirleyebilmek için cinsiyet, yaş, medeni durum, eğitim düzeyi, mesleki deneyim ile ilgili sorular sorulmuştur. Demografik veriler Tablo 1'de ayrıntılı olarak listelenmiştir. Ankette yer alan ifadelere cevap veren 296 katılımcının \%56,8'i kadın, \%43,2'si erkektir. Katılımcıların, \%42,9'u 25-30 yaş aralığında iken, \%34,8'i 30 yaş üstüdür. Geriye kalan \%22,3 oranındaki katılımcılar ise 25 yaşın altındadır. Katılımcıların \%43,9'u evli iken, \%56,1'i bekârdır. Katılımcıların 
$\% 55,1^{\prime} i$ lise mezunu, \%22'si ön lisans mezunu, \%11'i ise lisans mezunudur. Mesleki deneyim incelendiğinde ise katılımcıların \%5,7'si 1 yıldan az, \%29,1'i 1-4 yıl arası, \%38,2'si 5-9 yıl arası, \%27'si 10 yıldan fazla deneyime sahip olduğu belirlenmiştir.

Tablo 1. Demografik Özellikler

\begin{tabular}{|c|c|c|}
\hline Özellik & Frekans & (\%) \\
\hline \multicolumn{3}{|l|}{ Cinsiyet } \\
\hline Kadın & 168 & 56,8 \\
\hline Erkek & 128 & 43,2 \\
\hline \multicolumn{3}{|l|}{ Yaş } \\
\hline $25^{\prime}$ den $a z$ & 66 & 22,3 \\
\hline $25-30$ arası & 127 & 42,9 \\
\hline 31 yaş üstü & 103 & 34,8 \\
\hline \multicolumn{3}{|c|}{ Medeni durum } \\
\hline Bekar & 166 & 56,1 \\
\hline Evli & 130 & 43,9 \\
\hline \multicolumn{3}{|l|}{ Eğitim düzeyi } \\
\hline ilköğretim & 28 & 9,5 \\
\hline Lise & 163 & 55,1 \\
\hline Ön lisans & 65 & 22,0 \\
\hline Lisans & 33 & 11 \\
\hline Yüksek lisans & 7 & 2,4 \\
\hline \multicolumn{3}{|c|}{ Mesleki deneyim süresi } \\
\hline 1 yıldan az & 17 & 5,7 \\
\hline 1-4 yıl arası & 86 & 29,1 \\
\hline 5-9 yıl arası & 113 & 38,2 \\
\hline 10 yıl üzeri & 80 & 27,0 \\
\hline Toplam & 296 & 100 \\
\hline
\end{tabular}

\subsubsection{Tanımlayıcı İstatistikler}

Duygusal emek, tükenmişlik sendromu ve işten ayrılma niyeti için kullanılan ölçeklerin, normal dağılıp dağılmadığını test etmek için çarpıklık ve basıklık değerlerine bakılmıştır. Aritmetik ortalama ve standart sapma değerleri Tablo 2'de verilmiştir. Tablo 2'de görüldüğü üzere, veriler normal dağılım göstermektedir.

Tablo 2. Tanımlayıcı İstatistikler

\begin{tabular}{|l|c|c|c|c|}
\hline Sorular & Ort. & Std.S. & Çarpıklık & Basıklık \\
\hline Duygusal Emek & \multicolumn{5}{|l|}{} \\
\hline dyd1 & 3,06 & 1,38 & $-0,157$ & $-1,21$ \\
\hline dyd2 & 3,19 & 1,34 & $-0,245$ & $-1,12$ \\
\hline dyd3 & 3,11 & 1,31 & $-0,088$ & $-1,03$ \\
\hline dyd4 & 3,01 & 1,40 & $-0,063$ & $-1,25$ \\
\hline dyd5 & 2,86 & 1,46 & $-0,009$ & $-1,39$ \\
\hline dyd6 & 3,16 & 1,37 & $-0,219$ & $-1,03$ \\
\hline dry7 & 3,24 & 1,26 & $-0,280$ & $-0,930$ \\
\hline dry8 & 3,26 & 1,30 & $-0,340$ & $-0,974$ \\
\hline dry9 & 3,54 & 1,30 & $-0,621$ & $-0,729$ \\
\hline dry10 & 3,15 & 1,36 & $-0,237$ & $-1,14$ \\
\hline dsd11 & 3,23 & 1,52 & $-0,214$ & $-1,44$ \\
\hline dsd12 & 3,13 & 1,32 & $-0,127$ & $-1,13$ \\
\hline dsd13 & 3,33 & 1,34 & $-0,002$ & $-1,11$ \\
\hline
\end{tabular}


D. Keles - E. Aydin-Goktepe

Tablo 2. Tanımlayıcı İstatistikler (Devamı)

\begin{tabular}{|c|c|c|c|c|}
\hline \multicolumn{5}{|c|}{ Tükenmişlik Sendromu } \\
\hline $\mathrm{t} 1$ & 2,92 & 1,30 & $-0,005$ & $-1,06$ \\
\hline $\mathrm{t} 2$ & 3,32 & 1,24 & $-0,302$ & $-0,856$ \\
\hline t3 & 2,76 & 1,33 & 0,165 & $-1,10$ \\
\hline t4 & 3,83 & 1,01 & $-0,765$ & 0,233 \\
\hline t5 & 2,49 & 1,42 & 0,390 & $-1,23$ \\
\hline t6 & 3,48 & 1,29 & $-0,369$ & $-1,01$ \\
\hline t7 & 2,14 & 1,06 & 0,813 & 0,077 \\
\hline t8 & 3,15 & 1,42 & $-0,172$ & $-1,24$ \\
\hline t9 & 3,63 & 1,20 & $-0,566$ & $-0,583$ \\
\hline $\mathrm{t} 10$ & 2,89 & 1,51 & 0,125 & $-1,44$ \\
\hline $\mathrm{t} 11$ & 2,75 & 1,40 & 0,223 & $-1,19$ \\
\hline $\mathrm{t} 12$ & 3,93 & 1,29 & 1,76 & 0,680 \\
\hline $\mathrm{t} 13$ & 3,42 & 1,41 & $-0,406$ & $-1,11$ \\
\hline $\mathrm{t} 14$ & 3,72 & 1,27 & $-0,712$ & $-0,579$ \\
\hline $\mathrm{t} 15$ & 2,80 & 1,50 & 0,198 & $-1,38$ \\
\hline $\mathrm{t} 16$ & 3,41 & 1,38 & $-0,384$ & $-1,07$ \\
\hline $\mathrm{t} 17$ & 2,35 & 1,21 & 0,602 & $-0,572$ \\
\hline $\mathrm{t} 18$ & 2,79 & 1,46 & $-0,118$ & $-1,37$ \\
\hline $\mathrm{t} 19$ & 3,34 & 1,27 & 0,476 & $-0,702$ \\
\hline $\mathrm{t} 20$ & 2,94 & 1,56 & 0,015 & $-1,51$ \\
\hline $\mathrm{t} 21$ & 2,50 & 1,18 & 0,509 & $-0,542$ \\
\hline $\mathrm{t} 22$ & 2,97 & 1,44 & $-0,021$ & $-1,32$ \\
\hline \multicolumn{5}{|c|}{ İşten Ayrılma Niyeti } \\
\hline İan1 & 2,85 & 1,46 & 0,108 & $-1,38$ \\
\hline $\operatorname{Ian} 2$ & 3,41 & 1,51 & $-0,457$ & $-1,25$ \\
\hline İan3 & 3,05 & 1,44 & $-0,109$ & $-1,33$ \\
\hline
\end{tabular}

\subsubsection{Faktör Analizi}

Faktör analizinin uygulanabilmesi için KMO testi sonuçları incelenerek, veri setinin boyutu ve özelliklerinin faktör analizi için uygunluğuna bakılmıştır. KMO değeri ise 0 ile 1 arasında değişebilmektedir. Bu değer 1'e yaklaştıkça ölçekteki ifadelerin, hatasız bir şekilde tahmin etme gücü yükselmektedir (Durmuş, Çinko ve Yurtkoru, 2018: 78-80). Faktör analizinde, ölçekte yer alan soruların her birinin faktör yükü 0,50'nin üstünde olmalıdır (Cerny ve Kaiser, 1997).

Tablo 3'te KMO-Bartlett's Testi sonuçları yer almaktadır. Tablo 3'te verilen faktör analiz sonuçları $(p=0,000 ; \mathrm{KMO}=0,857)$, duygusal emek ölçeğinin faktör analizine uygun olduğunu göstermektedir.

Tablo 3. Duygusal Emek KMO-Bartlett's Testi Sonuçları

\begin{tabular}{|c|c|c|}
\hline \multicolumn{2}{|l|}{} & 0,857 \\
\hline \multirow{3}{*}{ Baiser-Meyer-Olkin Testi } & Ki Kare & 2084,87 \\
\cline { 2 - 3 } & df & 78 \\
\cline { 2 - 3 } & Sig. & 0,000 \\
\hline
\end{tabular}


Duygusal emek ölçeği için gerçekleştirilen faktör analizinde, derinlemesine davranış boyutuna ait 1 sorunun faktör yükü 0,50'in altında olduğu için analiz dışında tutulmuştur. Tablo 4'te faktör yükü düşük olan madde çıkarılarak yapılan duygusal emek ölçeği faktör analizi tablosu verilmiştir. Tablo 4'te duygusal emek ölçeğinde yer alan ifadelerin faktör yükleri ve varyans açıklama oranlarına yer verilmiştir. Tablo 4'te duygusal emek ölçeğinde yer alan soruların faktör yüklerinin 0,50 'den yüksek olduğu belirlenmiştir. Yapılan faktör analizi sonucunda, duygusal emek ölçeğindeki ifadeler "yüzeysel davranış", derinlemesine davranış" ve "samimi davranış" olarak 3 boyutta toplanmıştır. Bu faktörler ölçekteki ifadelerin varyansın \%69,44'ünü açıklamaktadır. Yüzeysel davranış faktörü varyansı \%37,22, derinlemesine davranış faktörü \%23,70 ve samimi davranış faktörü \%8,52 olarak belirlenmiştir.

Tablo 4. Duygusal Emek Ölçeği Faktör Analizi

\begin{tabular}{|c|c|c|c|}
\hline Boyut & ifadeler & $\begin{array}{l}\text { Faktör } \\
\text { Yükleri }\end{array}$ & $\begin{array}{l}\text { Varyans Açıklama } \\
\text { Oranı (\%) }\end{array}$ \\
\hline \multirow{6}{*}{ Yüzeysel Davranış } & dyd1 & 0,840 & \multirow{6}{*}{37,22} \\
\hline & dyd 2 & 0,813 & \\
\hline & dyd 3 & 0,759 & \\
\hline & dyd 4 & 0,739 & \\
\hline & dyd 5 & 0,709 & \\
\hline & dyd 6 & 0,542 & \\
\hline \multirow{3}{*}{$\begin{array}{l}\text { Derinlemesine } \\
\text { Davranış }\end{array}$} & drd1 & 0,848 & \multirow{3}{*}{23,70} \\
\hline & $\mathrm{drd} 2$ & 0,844 & \\
\hline & drd3 & 0,833 & \\
\hline \multirow{3}{*}{ Samimi Davranış } & dsd1 & 0,837 & \multirow{3}{*}{8,52} \\
\hline & $\mathrm{dsd} 2$ & 0,828 & \\
\hline & $\mathrm{ds} d 3$ & 0,793 & \\
\hline \multicolumn{3}{|c|}{ Toplam } & 69,44 \\
\hline
\end{tabular}

Tablo 5'te, tükenmişlik sendromu ölçeğinin KMO-Bartlett's Testi sonuçlarına yer verilmiştir. Tablo 5 'te verilen faktör analiz sonuçları $(p=0,000 ; K M O=0,935)$, tükenmişlik sendromu ölçeğinin faktör analizine uygun olduğunu göstermektedir.

Tablo 5. Tükenmişlik Sendromu Ölçeği KMO-Bartlett's Testi Sonuçları

\begin{tabular}{|l|c|c|}
\hline \multicolumn{2}{|l|}{ Kaiser-Meyer-Olkin Testi } & 0,935 \\
\hline \multirow{3}{*}{ Bartlett's Testi } & Ki Kare & 3646,28 \\
\cline { 2 - 3 } & df & 231 \\
\cline { 2 - 3 } & Sig. & 0,000 \\
\hline
\end{tabular}

Tükenmişlik sendromu ölçeğinden sekiz soru yeterli faktör yükü olan 0,50 faktör yükünün altında olduğu için analiz dışında tutulmuştur. Tablo $6^{\prime}$ da faktör yükü düşük olan maddeler çıkarılarak yapılan faktör analizi tablosu verilmiştir. Tablo 6 'da tükenmişlik sendromu ölçeğinde yer alan ifadelerin faktör yükleri ve varyans açıklama oranlarına yer verilmiştir. Yapılan faktör analizi sonucunda, tükenmişlik sendromu ölçeğindeki ifadeler 1 boyutta toplanmıştır. Bu faktörler ölçekteki ifadelerin varyansın \%56,96'ini açıklamaktadır. 
Tablo 6. Tükenmişlik Sendromu Ölçeği Faktör Analizi

\begin{tabular}{|c|c|c|c|}
\hline Boyut & ifadeler & $\begin{array}{l}\text { Faktör } \\
\text { Yükleri }\end{array}$ & $\begin{array}{l}\text { Varyans Açıklama } \\
\text { Oranı (\%) }\end{array}$ \\
\hline \multirow{14}{*}{$\begin{array}{l}\text { Tükenmişlik } \\
\text { Sendromu }\end{array}$} & $\mathrm{t} 1$ & 0,839 & \multirow{14}{*}{41,52} \\
\hline & t2 & 0,733 & \\
\hline & t3 & 0,841 & \\
\hline & t4 & 0,856 & \\
\hline & t5 & 0,756 & \\
\hline & t6 & 0,847 & \\
\hline & $\mathrm{t7}$ & 0,817 & \\
\hline & t8 & 0,687 & \\
\hline & t9 & 0,724 & \\
\hline & $\mathrm{t} 10$ & 0,639 & \\
\hline & $\mathrm{t} 11$ & 0,647 & \\
\hline & $\mathrm{t} 12$ & 0,739 & \\
\hline & $\mathrm{t} 13$ & 0,775 & \\
\hline & $\mathrm{t} 14$ & 0,643 & \\
\hline \multicolumn{2}{|r|}{ Toplam } & & 56,96 \\
\hline
\end{tabular}

Tablo 7'de işten ayrılma niyeti ölçeğinin KMO-Bartlett's Testi sonuçlarına yer verilmiştir. Tablo 7'de verilen faktör analiz sonuçları $(p=0,000 ; \mathrm{KMO}=0,745)$, işten ayrılma niyeti ölçeğinin faktör analizine uygun olduğunu göstermektedir.

Tablo 7. İşten Ayrılma Niyeti Ölçeği KMO-Bartlett's Testi Sonuçları

\begin{tabular}{|l|c|c|}
\hline \multicolumn{2}{|l|}{} & 0,745 \\
\hline \multirow{3}{*}{ Kaiser-Meyer-Olkin Testi } & Ki Kare & 739,98 \\
\cline { 2 - 3 } & df & 3 \\
\cline { 2 - 3 } & Sig. & 0,000 \\
\hline
\end{tabular}

Tablo 8'de işten ayrılma niyeti ölçeğinde yer alan ifadelerin faktör yükleri, varyans ve açıklama oranı yer verilmiştir. Yapılan faktör analizi sonucunda, işten ayrılma niyeti ölçeğindeki ifadeler 1 boyutta toplanmıştır. Bu faktör işten ayrılma niyetini temsil etmektedir. Bu faktör varyansın \%87,59'sini açıklamaktadır.

Tablo 8. İşten Ayrılma Niyeti Ölçeği Faktör Analizi

\begin{tabular}{|l|c|c|c|}
\hline \multirow{2}{*}{ Boyut } & ifadeler & $\begin{array}{c}\text { Faktör } \\
\text { Yükleri }\end{array}$ & $\begin{array}{c}\text { Varyans Açıklama } \\
\text { Oranı (\%) }\end{array}$ \\
\hline \multirow{2}{*}{$\begin{array}{l}\text { işten Ayrıma } \\
\text { Niyeti }\end{array}$} & ian1 & 0,952 & \multirow{2}{*}{87,59} \\
\cline { 2 - 3 } & ian1 & 0,911 & \multirow{2}{*}{87,59} \\
\cline { 2 - 3 } & ian1 & 0,944 & 87,59 \\
\hline \multicolumn{3}{|c|}{ Toplam } \\
\hline Ian: işten ayrılma niyeti
\end{tabular}

\subsubsection{Güvenilirlik Analizi}

Araştırmada kullanılan ölçümlerin güvenilirliğini test etmek için, güvenilirlik analizi yapılmış ve Cronbach's Alpha katsayısının elde edildiği güvenilirlik analizi kullanılmıştır. Tablo 9'da da belirtildiği gibi ölçeklerin güvenilirlik değerleri duygusal emek ölçeğinin $(\alpha=0,884)$, tükenmişlik sendromu ölçeğinin 
$(\alpha=0,910)$, işten ayrılma niyeti ölçeğinin $(\alpha=0,930)^{\prime}$ dur. Duygusal emek ölçeğinin alt boyutlarının güvenilirlik değerleri yüzeysel davranışın $(\alpha=0,871)$, derinlemesine davranışın $(\alpha=0,872)$, samimi davranışın $(\alpha=0,874)^{\prime}$ tür. Güvenilirlik analizinde, $\alpha>0,70$ kabul edilebilir bir değer olması sebebiyle tüm faktörlerin güvenilir oldukları belirlenmiştir.

Tablo 9. Güvenilirlik Analizi Sonuçları

\begin{tabular}{|l|l|c|c|}
\hline \multicolumn{2}{|l|}{ Değişkenler } & ifade Sayısı & Cronbach's Alpha ( $\boldsymbol{\alpha})$ \\
\hline \multirow{2}{*}{$\begin{array}{l}\text { Duygusal emek } \\
\text { alt boyutları }\end{array}$} & Yüzeysel davranış & 6 & 0,871 \\
\cline { 2 - 4 } & Derinlemesine davranış & 3 & 0,882 \\
\cline { 2 - 4 } & Samimi davranış & 3 & 0,874 \\
\hline Duygusal emek & 12 & 0,884 \\
\hline \multicolumn{2}{|l|}{ Tükenmişlik sendromu } & 14 & 0,910 \\
\hline \multicolumn{2}{|l|}{ Iş̧ten ayrıma niyeti } & 3 & 0,930 \\
\hline
\end{tabular}

\subsubsection{Korelasyon Analizi}

Korelasyon analizinde her iki değişken arasında ilişki olup olmadığı ve varsa bu ilişkinin derecesi, Pearson korelasyon katsayısı (r) ile belirlenir. (Kalaycı, 2010: 115) Bu bölümde araştırmaya katılanların duygusal emek davranışlarının, tükenmişlik sendromu ve işten ayrılma niyeti ile ilişkisi ve bu ilişkinin derecesini belirlemek amacıyla korelasyon analizi yapılmıştır. Korelasyon analizi sonuçlarına Tablo $10^{\prime}$ da yer verilmiştir.

Tablo 10 incelendiğinde, yüzeysel davranış ve tükenmişlik sendromu arasında $(r=0,639, p<0,01)$ pozitif ve anlamlı yönde bir ilişki saptanmıştır. Yüzeysel davranış ve işten ayrılma niyeti arasında $(r=0,481$, $p=0,000<0,001)$ pozitif ve anlamlı yönde bir ilişki saptanmıştır. Samimi davranış ve tükenmişlik sendromu arasında $(r=0,624, p=0,000<0,001)$ pozitif ve anlamlı yönde bir ilişki saptanmıştır. Samimi davranış ve işten ayrılma niyeti arasında $(r=0,541, p<0,01)$ pozitif ve anlamlı yönde bir ilişki saptanmıştır. Tükenmişlik sendromu ve işten ayrılma niyeti arasında $(r=0,704, p=0,000<0,001)$ pozitif ve anlamlı yönde bir ilişki saptanmıştır. Diğer taraftan ise derinlemesine davranış ve tükenmişlik sendromu arasında ( $r=-0,044$, $p=0,455>0,001)$ istatistiksel yönden anlamlı bir ilişki tespit edilememiştir. Derinlemesine davranış ve işten ayrılma niyeti arasında $(r=-0,021, p=0,723<0,001)$ istatistiksel yönden anlamlı bir ilişki tespit edilememiştir.

Tablo 10. Korelasyon Analizi Sonuçları

\begin{tabular}{|c|c|c|c|c|c|c|}
\hline & & dyd & drd & dsd & $t$ & ian \\
\hline \multirow{3}{*}{$\begin{array}{l}\text { Yüzeysel } \\
\text { davranış (dyd) }\end{array}$} & $r$ & 1,000 & & & & \\
\hline & $p$ & & & & & \\
\hline & $n$ & 296 & & & & \\
\hline \multirow{3}{*}{$\begin{array}{l}\text { Derinlemesine } \\
\text { davranış } \\
\text { (drd) }\end{array}$} & $r$ & 0,087 & 1,000 & & & \\
\hline & $p$ & 0,133 & & & & \\
\hline & $\mathrm{n}$ & 296 & 296 & & & \\
\hline \multirow{3}{*}{$\begin{array}{l}\text { Samimi davranış } \\
\text { (dsd) }\end{array}$} & $r$ & $0,507^{* *}$ & $-0,283^{* *}$ & 1,000 & & \\
\hline & $p$ & 0,000 & 0,000 &. & & \\
\hline & $\mathrm{n}$ & 296 & 296 & 296 & & \\
\hline \multirow{3}{*}{$\begin{array}{l}\text { Tükenmişlik } \\
\text { sendromu (t) }\end{array}$} & $r$ & $0,639 * *$ & $-0,044$ & $0,624^{* *}$ & 1,000 & \\
\hline & $p$ & 0,000 & 0,455 & 0,000 & 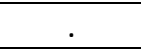 & \\
\hline & $n$ & 296 & 296 & 296 & 296 & \\
\hline \multirow{3}{*}{$\begin{array}{l}\text { İşten ayrılma } \\
\text { niyeti (ian) }\end{array}$} & $r$ & $0,481 * *$ & $-0,021$ & $0,541^{* *}$ & $0,704^{* *}$ & 1,000 \\
\hline & $p$ & 0,000 & 0,723 & 0,000 & 0,000 & \\
\hline & $\mathrm{n}$ & 296 & 296 & 296 & 296 & 296 \\
\hline
\end{tabular}




\subsubsection{Regresyon Analizi Sonuçları}

Çalışanların duygusal emek davranışlarının tükenmişlik sendromu üzerine etkisini belirlemeye yönelik yapılan regresyon analizi sonuçları Tablo $11^{\prime}$ de verilmiştir. Tablo 11 'de VIF değerlerinin $10^{\prime}$ dan düşük ve tolerans değerlerinin $0,10^{\prime}$ dan büyük olması, çoklu doğrusallık sorunu olmadığını göstermektedir. Tablo $11^{\prime} \mathrm{e}$ göre duygusal emek davranışları, tükenmişlik sendromundaki değişkenliğin $\% 25^{\prime}$ ini $\quad\left(R^{2}=0,246\right)$ açıklayabilmektedir. Regresyon modelinin istatistiksel açıdan anlamlı $(F=159,913 ; p=0,000<0,001)$ olduğu belirlenmiştir. Analize göre, yüzeysel davranışın tükenmişlik sendromu üzerinde pozitif yönde ve anlamlı $(\beta=0,435 t=9,307, p=0,000<0,001)$ bir etkiye sahip olduğu belirlenmiştir. Derinlemesine davranışın tükenmişlik sendromu üzerindeki etkisi anlamlı $(\beta=0,026 \mathrm{t}=9,307, p=0,000>0,001)$ olmadığı belirlenmiştir. Samimi davranışın tükenmişlik sendromu üzerindeki etkisinin pozitif yönde ve anlamlı $(\beta=0,446 \mathrm{t}=8,700$, $p=0,000<0,001$ ) bir etkiye sahip olduğu belirlenmiştir. Başka bir deyişle, yüzeysel davranıştaki 1 birimlik artış tükenmişlik sendromu üzerinde 0,435' Iık bir artışa, samimi davranıştaki 1 birimlik artış tükenmişlik sendromu üzerinde $0,446^{\prime}$ Iık bir artışa neden olmaktadır. Regresyon analizi sonuçlarına dayanarak, H1a ve H1b hipotezlerinin desteklenmiş, $\mathrm{H} 1 \mathrm{c}$ hipotezinin desteklenmemiş olduğu sonucuna varılmıştır.

Tablo 11. Duygusal Emek Davranışının Tükenmişlik Sendromu Üzerindeki Etkisi

\begin{tabular}{|c|c|c|c|c|c|c|c|}
\hline \multirow[b]{2}{*}{ Model } & \multicolumn{7}{|c|}{ Bağımlı Değişken: Tükenmişlik Sendromu } \\
\hline & Bağımsız Değişken & $\begin{array}{l}\text { Std. } \\
\text { Hata }\end{array}$ & Beta & $\mathrm{t}$ & $\mathrm{p}$ & Tolerans & VIF \\
\hline \multirow{10}{*}{1} & Sabit & 0,202 & & 16,457 & 0,000 & & \\
\hline & Yüzeysel Davranış & 0,044 & $0,435^{*}$ & 9,307 & 0,000 & 0,734 & 1,362 \\
\hline & Derinlemesine Dav. & 0,063 & 0,026 & 0,59 & 0,055 & 0,904 & 1,106 \\
\hline & Samimi Davranış & 0,040 & $0,446^{*}$ & 8,700 & 0,000 & 0,723 & 1,383 \\
\hline & $\mathrm{R}^{2}$ & 0,246 & & & & & \\
\hline & Düzeltilmiş $\mathrm{R}^{2}$ & 0,240 & & & & & \\
\hline & $\mathrm{F}$ & 15,286 & & & & & \\
\hline & $p$ & 0,000 & & & & & \\
\hline & Durbin-Watson & 1,882 & & & & & \\
\hline & \multicolumn{7}{|l|}{$* \mathrm{p}<0,001$} \\
\hline
\end{tabular}

Çalışanların duygusal emek davranışlarının işten ayrılma niyeti üzerindeki etkisini belirlemeye yönelik yapılan regresyon analizi sonuçları Tablo 12 'de verilmiştir. Tablo 12 'de VIF değerlerinin $10^{\prime}$ dan düşük ve tolerans değerlerinin $0,10^{\prime}$ dan büyük olması, çoklu doğrusallık sorunu olmadığını göstermektedir. Tablo $12^{\prime} \mathrm{e}$ göre duygusal emek davranışları, işten ayrılma niyetindeki değişkenliğin \%33'ünü $\left(R^{2}=0,334\right)$ açıklayabilmektedir. Regresyon modelinin istatistiksel açıdan anlamlı ( $F=159,913 ; p=0,000<0,001)$ olduğu belirlenmiştir. Analize göre, yüzeysel davranışın işten ayrılma niyeti üzerindeki etkisinin pozitif ve anlamlı $(\beta=0,584 t=5,243, p=0,000<0,001)$ olduğu belirlenmiştir. Derinlemesine davranışın işten ayrılma niyeti üzerindeki etkisi istatistiksel olarak anlamlı $(\beta=0,072, t=1,517, p=0,000>0,001)$ olmadığı belirlenmiştir. Samimi davranışın işten ayrılma niyeti üzerindeki etkisinin pozitif yönde ve anlamlı $(\beta=0,480 \mathrm{t}=7,357$, $p=0,000<0,001$ ) bir etkiye sahip olduğu belirlenmiştir. Başka bir deyişle, yüzeysel davranıştaki 1 birimlik artış işten ayrılma niyeti üzerinde 0,584'lük bir artışa, samimi davranıştaki 1 birimlik artış işten ayrıma niyeti üzerinde $0,480^{\prime}$ lik bir artışa neden olacaktır. Regresyon analizi sonuçlarına dayanarak, H2a ve H2b hipotezlerinin desteklenmiş olduğu, $\mathrm{H} 2 \mathrm{c}$ hipotezinin desteklenmemiş olduğu sonucuna varılmıştır. 
Tablo 12. Duygusal Emek Davranışının İşten Ayrılma Niyeti Üzerindeki Etkisi

\begin{tabular}{|c|c|c|c|c|c|c|c|}
\hline \multirow[b]{2}{*}{ Model } & \multicolumn{7}{|c|}{ Bağımlı Değişken: İşten Ayrılma Niyeti } \\
\hline & Bağımsız Değişken & $\begin{array}{l}\text { Std. } \\
\text { Hata }\end{array}$ & Beta & $\mathrm{t}$ & $\mathrm{p}$ & Tolerans & VIF \\
\hline \multirow{10}{*}{2} & Sabit & 0,205 & & 3,783 & 0,00 & & \\
\hline & Yüzeysel Davranış & 0,077 & $0,584^{*}$ & 5,243 & 0,00 & 0,734 & 1,36 \\
\hline & Derinlemesine Dav. & 0,038 & 0,072 & 1,517 & 0,130 & 0,904 & 1,10 \\
\hline & Samimi Davranış & 0,084 & $0,480 *$ & 7,357 & 0,00 & 0,723 & 1,38 \\
\hline & $\mathrm{R}^{2}$ & 0,334 & & & & & \\
\hline & Düzeltilmiş $\mathrm{R}^{2}$ & 0,320 & & & & & \\
\hline & $\mathrm{F}$ & 79,82 & & & & & \\
\hline & $p$ & 0,000 & & & & & \\
\hline & Durbin-Watson & 1,922 & & & & & \\
\hline & \multicolumn{7}{|l|}{$* p<0,001$} \\
\hline
\end{tabular}

Yapılan analizler sonunda araştırma hipotezlerinin desteklenip, desteklenmediği Tablo 13'te özet halinde verilmiştir.

Tablo 13. Araştırma Sonucu Hipotezlerin Değerlendirmesi

\begin{tabular}{|ll|}
\hline Hipotez & Sonuç \\
\hline $\begin{array}{l}\text { H1a: Hazır giyim sektöründe çalışanların yüzeysel davranışlarının, } \\
\text { tükenmişlik sendromu üzerinde pozitif yönde bir etkisi vardır. }\end{array}$ & Desteklendi \\
\hline $\begin{array}{l}\text { H1b: Hazır giyim sektöründe çalışanların samimi davranışlarının, } \\
\text { tükenmişlik sendromu üzerinde pozitif yönde bir etkisi vardır. }\end{array}$ & Desteklendi \\
\hline $\begin{array}{l}\text { H1c: Hazır giyim sektöründe çalışanların derinlemesine davranışlarının, } \\
\text { tükenmişlik sendromu üzerinde negatif yönde bir etkisi vardır. }\end{array}$ & Desteklenmedi \\
\hline $\begin{array}{l}\text { H2a: Hazır giyim sektöründe çalışanların yüzeysel davranışlarının, işten } \\
\text { ayrılma niyeti üzerinde pozitif yönde bir etkisi vardır. }\end{array}$ & Desteklendi \\
\hline $\begin{array}{l}\text { H2b: Hazır giyim sektöründe çalışanların samimi davranışlarının, işten } \\
\text { ayrılma niyeti üzerinde pozitif yönde bir etkisi vardır. }\end{array}$ & Desteklendi \\
\hline $\begin{array}{l}\text { H2c: Hazır giyim sektöründe çalışanların derinlemesine davranışlarının, } \\
\text { işten ayrılma niyeti üzerinde negatif yönde bir etkisi vardır. }\end{array}$ & Desteklenmedi \\
\hline
\end{tabular}

\section{Tartışma}

Duygusal emek işletmenin beklentilerini karşılayabilmek, müşteriyi ikna etmek ve etkilemek için bir ücret karşıı̆ı̆ında, çalışanın duygularını bastırması ve yönetmesi olarak ifade edilmektedir (Hochschild, 1983). Bu bölümde, araştırma hipotezlerinin literatür ile uyumlu olup olmadığı tartışımıştır.

Araştırmanın H1a hipotezi "Hazır giyim sektöründe çalışanların yüzeysel davranışlarının, tükenmişlik sendromu üzerinde pozitif yönde bir etkisi vardır" desteklenmiştir. Yüzeysel davranış, çalışanın gerçekten hissetmediği duyguları hissediyormuş gibi tavır ve davranışlarında değişiklik yapması anlamına gelir (Hochschild, 1983). Yapılan bir araştırmada da yüzeysel davranışın, tükenmişliğin alt boyutlarından duygusal tükenme ve duyarsızlaşma ile ilişkili olduğu belirlenmiştir. Aynı çalışmada yüzeysel davranış ile kişisel başarı hissinde azalma arasında ilişkisi bulunmadığı belirtilmiştir (Eroğlu, 2014). Buna göre yüzeysel davranış sergileyen satış görevlileri daha fazla rol yapmak zorunda kaldıkları için tükenmişliği daha yoğun yaşamaktadır. Literatürde bu hipotezi destekler nitelikte birçok araştırma yapılmıştır (Grandey, 1999; Furnell, 2008; Oral ve Köse, 2011; Yılmaz, Altınkurt, Güner ve Şen, 2015; Güler ve Marşap, 2019). 
Araştırmanın H1b hipotezi, "Hazır giyim sektöründe çalışanların samimi davranışlarının, tükenmişlik sendromu üzerinde pozitif yönde bir etkisi vardır" desteklenmiştir. Bu duruma göre satış görevlilerinin samimi davranışları arttıkça tükenmişlik sendromu da artacaktır. Samimi davranışın, tükenmişlik sendromu üzerindeki etkisini inceleyen çalışmaların sonuçları, samimi davranış ve tükenmişlik sendromunun boyutlarını arasındaki ilişkiyi göstermektedir. (Kaya ve Çelik vd., 2011; Özhan, 2012). Bu nedenle H1b hipotezinin desteklenmiş olmasının, literatür ile uyumlu olup olmadığını belirlemek için bu çalışmalar ile kıyaslama yapılabilecektir. Elde edilen bu sonucun, samimi davranışların, tükenmişlik sendromunun boyutu olan kişisel başarı hissinin azalması üzerinde pozitif etkisi olduğunu belirten çalışmalarla uyumlu, samimi davranışların, tükenmişlik sendromunun boyutu olan duyarsızlaşma ile negatif ilişkili olduğunu belirten çalışmalarla uyumlu olmadığı söylenebilir (Çelik vd., 2011; Kaya ve Özhan, 2012).

Araştırmanın H1c hipotezi "Hazır giyim sektöründe çalışanların derinlemesine davranışlarının, tükenmişlik sendromu üzerinde negatif yönde bir etkisi vardır" desteklenmemiştir. Derinlemesine davranış işletmenin kendisinden beklediği davranışlarla çalışanın kendi hislerini ve davranışlarını uyumlu hale getirme çabası anlamına gelir (Beğenirbaş, 2013). Daban (2018)'ın, derinlemesine davranışlar ile duygusal tükenme ve duyarsızlaşma arasında anlamlı bir ilişki olmadığını gösteren çalışması ile bu araştırmanın sonuçları uyumludur.

Araştırmanın $\mathrm{H} 2 \mathrm{a}$ hipotezi "Hazır giyim sektöründe çalışanların yüzeysel davranışlarının, işten ayrılma niyeti üzerinde pozitif yönde bir etkisi vardır" desteklenmiştir. Buna göre yüzeysel davranış sergileyen bir satış görevlisinin işten ayrılma niyeti artacaktır. Literatürde bu hipotezi destekler nitelikte çalışmalar oldukça fazladır ve literatürde yer alan çalışmalar, yüzeysel davranışın işten ayrılma niyetiyle pozitif yönlü ilişkisinin olduğunu belirtmişlerdir (Çaldağ, 2010; Yürür ve Ünlü, 2011; Yeşil ve Mavi, 2018; Güler ve Marşap, 2019).

Araştırmanın $\mathrm{H} 2 \mathrm{~b}$ hipotezi "Hazır giyim sektöründe çalışanların samimi davranışlarının, işten ayrılma niyeti üzerinde pozitif yönde bir etkisi vardır" desteklenmiştir. Bu sonuca göre samimi davranış gösteren bir satış görevlisinin işten ayrıma niyetinde artış görülecektir. Literatürde yer alan çalışmalarda, duygusal emek davranışları derinlemesine davranış ve yüzeysel davranış olarak iki boyut olarak ele alınmıştır. Bu nedenle samimi davranış ve işten ayrılma niyeti ilişkisine yönelik literatürde, $\mathrm{H} 2 \mathrm{~b}$ hipotezi için gerçekleştirilen analiz sonuçlarını kıyaslayacak çalışma bulunamamıştır.

Araştırmanın $\mathrm{H} 2 \mathrm{c}$ hipotezi "Hazır giyim sektöründe çalışanların derinlemesine davranışlarının, işten ayrılma niyeti üzerinde negatif yönde bir etkisi vardır" desteklenmemiştir. Buna göre derinlemesine davranışı artan bir satış görevlisinin işten ayrılma niyeti üzerinde anlamlı bir etkisi bulunmamıştır. Elde edilen bulgularla alan yazında paralellik gösteren çalışmalar mevcuttur (Öz, 2007; Yang ve Chang, 2008; Yeşil ve Mavi, 2018).

\section{Sonuç ve Öneriler}

Bu araştırmada dört farklı hazır giyim markasının İstanbul'daki dört farklı ilçedeki (Şişli, Bakırköy, Beylikdüzü, Bayrampaşa) cadde üstü ve alışveriş merkezi mağazalarında çalışan satış görevlilerinin duygusal emek davranışlarının, tükenmişlik düzeyleri ve çalışanların işten ayrılma niyeti üzerindeki etkisi belirlenmeye çalışılmıştır. Araştırma sınırlııklarından ilki; veri toplamadaki zaman ve maliyet kısıtlarından dolayı araştırmada üç farklı marka ve bu markaların İstanbul ilinin dört ilçesindeki mağazalarında çalışan satış görevlileri ile sınırlı tutulmuş olmasıdır. Bu araştırmada, diğer hazır giyim markaları ve araştırmaya dahil edilen markaların belirlenen dört ilçesi haricindeki satış görevlileri kapsam dışı bırakılmıştır. Çalışmanın İstanbul ili ile sınırlı tutulmuş olması, elde edilen sonuçların Türkiye ölçeğinde yorumlanmasında da kısıt oluşturmaktadır. Bir diğer kısıt ise araştırmada sadece nicel araştırma yöntemi kullanılmış olmasıdır. Araştırma değişkenlerine ve aralarındaki ilişkilere yönelik daha derinlemesine bilgi edinilmesi için nitel araştırma yöntemlerinin de kullanılmamış olması, çalışmada elde edilen bulguların yorumlanmasını kısıtlamıştır.

Duygu yönetiminin giderek daha da önemli olduğu göz önünde bulundurulduğunda, duygusal emek yazınına katkı sağlayacak çalışmaların çeşitlendirilmesi ve farklı değişkenlerle ilişkilerinin de incelenmesi literatüre katkı sağlayacaktır. Elde edilen sonuçlar ışığında araştırmacılara gelecekte yapacakları araştırmalara işe yabancılaşma, içsel işten ayrılma, algılanan yönetici desteği, kurumsal aidiyet gibi değişkenleri de dahil 
ederek, duygusal emek davranışlarının bu değişkenler üzerindeki etkisini incelemeleri önerilebilir. Ayrıca gelecekte yapılacak araştırmalarda, duygusal emek davranışının, işten ayrılma niyeti ve tükenmişlik düzeyi üzerindeki etkisini açıklamak için bu etkide rolü olabilecek iş yükü, mola süreleri, iş-yaşam dengesi, lider-üye etkileşimi gibi değişkenlerin düzenleyici etkisi araştırılmalıdır.

Elde edilen sonuçlar ışığında perakendecilik sektöründe çalışmakta olan yöneticilere ve işletmelere de önerilerde bulunulabilir. Çalışanların yüzeysel davranışlarının, tükenmişlik sendromu ve işten ayrılma niyeti üzerinde pozitif yönde bir etkisi olduğu belirlenmiştir. Çalışanların hissetmediği fakat kendisinden işletmenin beklediği davranışları sergileyen çalışanların, tükenmişlik düzeylerinin ve işten ayrılma niyetini artırdığı görülmektedir. Tükenmiş düzeyini ve işten ayrılma niyetini azaltmak adına çalışanların rol yapmak yerine, işletmenin istediği davranışları gerçekten hissetmesini sağlayacak, çalışanın işletmeyi daha çok benimsemesini ve özdeşleşmesini sağlayacak uygulamalar gerçekleştirmeleri önerilebilir. Araştırmanın bir diğer sonucu olarak; çalışanların samimi davranışlarının, tükenmişlik sendromu ve işten ayrılma niyeti üzerinde pozitif yönde bir etkisi olduğu belirlenmiştir. İ̧̧letmenin kendisinden beklediği, sergilemek zorunda olduğu davranışları, zaten var olan duyguları ile gerçekleştiren çalışanların tükenmişlik sendromu ve işten ayrılma niyetinin arttığı görülmektedir. Araştırma sonunda elde edilen bu ilginç sonuç şu örnekle açıklanabilir; müşterisi ile kurduğu olumlu ilişki nedeniyle yemek molasına çıkmayıp güler yüzle hizmet vermeye ya da iş dışında yaşamış olduğu problemler olmasına rağmen güler yüzle hizmet etmeye devam etmek samimi davranıştır. Bu nedenle samimi davranış gösteren kişi, mola süreleri ya da özel yaşam kaynaklı problemleri nedeniyle işten ayrılmak istiyor olabilir ya da tükenmişlik sendromu yaşıyor olabilir. Araştırma sonucunda elde edilen bu bulgu, samimi davranış gösteren yani işletmenin istediği iş davranışlarını hissederek gerçekleştiren çalışanın, tükenmişlik düzeyinin ve işten ayrılma niyetinin yüksek olmasında farklı etkenlerin de olabileceği şeklinde yorumlanabilir. Çalışanın iş dışında yaşadığı problemlerin belirlenmesi, bu problemlerin üstesinden gelebilmesi için yöneticisi ya da işletmecisi tarafından araçsal, maddi, sosyal, psikolojik olarak desteklenmesi gerekebilir. Çalışanın samimi davranış gösterebiliyor olmasına rağmen tükenmişlik düzeyinde ve işten ayrılma niyetinde artış olmasında, yönetici ile kurduğu ilişki, iş yükünün fazla olması, mola saatlerinin makul düzenlenmemiş olması gibi örgütsel faktörler de etkili olabilir. Samimi davranış sergileyen bireylerin, tükenmişlik düzeyinin ve işten ayrılma niyetinin yüksek olma nedenlerini belirleyebilmek ve yöneticilere önerilerde bulunmak için nitel araştırma yöntemleri ile bulguların yorumları zenginleştirilebilir.

\section{Beyan ve Açıklamalar (Disclosure Statements)}

1. Bu çalışmanın yazarları, araştırma ve yayın etiği ilkelerine uyduklarını kabul etmektedirler (The authors of this article confirm that their work complies with the principles of research and publication ethics).

2. Yazarlar tarafından herhangi bir çıkar çatışması beyan edilmemiştir (No potential conflict of interest was reported by the authors).

3. Bu çalışma, intihal tarama programı kullanılarak intihal taramasından geçirilmiştir (This article was screened for potential plagiarism using a plagiarism screening program).

\section{Kaynaklar}

Akçay, C., \& Çoruk, A. (2012). Çalışma yaşamında duygular ve yönetimi: Kavramsal bir inceleme. Eğitimde Politika Analizi Dergisi, 1(1), 3-25.

Ashforth, B., \& Humprey, R. (1993). Emotional labor in service roles: The influence of identitiy. The Academy of Management Rewiev, 18(1), 88-115.

Aydın Göktepe, E., \& Keleş D. (2019). İ̧̧yeri nezaketsizliği ve işten ayrılma eğilimi ilişkisi: Akademik personel üzerine bir araştırma. Sosyal Araştırmalar ve Davranış Bilimleri Dergisi, 5(12), 262-273.

Beğenirbaş, M., \& Basım, N. (2012). Duygusal emekte baz demografik değişkenlerin rolü: Görgül bir araştırma. Çankaya University Journal of Humanities and Social Sciences, 10(1), 45-57. 
Beğenirbaş, M. (2013). Kişiliğin öğretme stillerine etkisinde duygusal emek ve tükenmişliğin aracılık rolü: Öğretmenler üzerinde bir araştırma. Kara Harp Okulu Savunma Bilimleri Enstitüsü, Yayınlanmamış Doktora Tezi, Ankara.

Bıyık, Y., \& Aydoğan, E. (2014). Duygusal emek ile örgütsel vatandaşlık davranışı ilişkisi: Bir araştırma. Gazi Üniversitesi iiBF Dergisi, 16(3), 159-180.

Brotheridge, C., \& Grandey, A. (2002). Emotional labor and burnout: Comparing two perspectives of "people work". Journal of Vocational Behavior, 60(1), 17-39.

Cerny, B. A., \& Kaiser, H. F. (1977). A study of a measure of sampling adequacy for factor analytic correlation matrices. The Journal of the Society of Multivariate Experimental Psychology, 12(1), 43-47.

Chu, K., \& Murmann, S. (2006). Development and validation of the hospitality emotional labor scale. Tourism Management, 27(6), 1181-1191.

Çelik, M., Tabak, A., Uysal, M. P., Sıgrı, Ü., \& Turunç, Ö. (2011). The relationship between burnout and emotional labour of the employees in hospital sector. International Journal of Business and Management Studies, 2(1), 47-54.

Çoruk, A. (2014). Yükseköğretim kurumlarında görev yapan idari personelin duygusal emek davranışları. Ondokuz Mayıs Üniversitesi Eğitim Fakültesi Dergisi, 33(1), 79-93.

Durmuş, B., Çinko, M., \& Yurtkoru, S. E. (2018). Sosyal bilimlerde veri SPSS'le veri analiz. İstanbul: Beta Yayınları.

Daban, B. (2018). Ortaokul öğretmenlerinin duygusal emek ile tükenmişlik düzeyleri arasındaki ilişkinin incelenmesi. Recep Tayyip Erdoğan Üniversitesi, Yayınlanmamış Yüksek Lisans Tezi, Rize.

Diefendorf, J., \& Gosserand, R. (2003). Understanding the emotional labor process: A control theory perspective. Journal of Organizational Behaviour, 24(8), 945-959.

Diefendorff, J. M., Croyle, M. H., \& Gosserand, R. H. (2005). The dimensionality and antecedents of emotional labor strategies. Journal of Vocational Behavior, 66(2), 339-357.

Dworkin, A. G., Saha, L. J., \& Hill, A. N. (2003). Teacher burnout and perceptions of a democratic school environment. International Education Journal, 4, 108-120.

Ergin, C. (1992). Doktor ve hemşirelerde tükenmişlik ve Maslach tükenmişlik ölçeğinin uyarlanması. VII. Ulusal Psikoloji Kongresi Bilimsel Çalışmaları, 143-154.

Eroğlu, Ş. (2014). Örgütlerde duygusal emek ve tükenmişlik üzerinde bir araştırma. Pamukkale Üniversitesi Sosyal Bilimler Enstitüsü Dergisi, 19(17), 147-160.

Ersoy, A., \& Utku, B. (2005). Konaklama işletmeleri muhasebe müdürlerinde tükenmişlik sendromu-1. Muhasebe ve Finansman Dergisi, 26, 38-46.

Freudenberger, H. J. (1974). Staff burnout. Journal of Social Issues, 30, 159-165.

Furnell, A. (2008). Exploring the relationship between burnout, emotional labour and emotional intelligence: A study on call centre representatives. Industrial Psychology at The University of Stellenbosch, Master Dissertation, South Africa.

Grandey, A. (2000). Emotion regulation in the workplace: A new way to conceptualize emotional labor. Journal of Occupational Health Psychology, 5(1), 95-110.

Grandey, A. A. (1999). The effects of emotional labor: Employee attitudes, stress and performance. Colorado State University, Doctoral Thesis, Colorado, USA.

Grandey, A., Fisk, G., Mattila, A., Karen J., \& Lori, S. (2005). Is "service with a smile" enough? Authenticity of positive displays during service encounters. Organizational Behavior and Human Decision Processes, 96, 38-55.

Griffeth, R., Hom, P., \& Gaertner, S. (2000). A meta-analysis of antecedents and correlates of employee turnover: Update, moderator tests and research implications for the next millennium. Journal of Management, 26(3), 463488.

Güler, H. N., \& Marşap, A. (2018). Duygusal emek, tükenmişlik ve işten ayrılma niyeti: Cinsiyet ve iş deneyimine göre farklılıkların incelenmesi. İşletme Araştırmaları Dergisi, 10(3), 488-507.

Gülova, A. A., Palamutçuoğlu B. T., \& Palamutçuoğlu, A. T. (2013). Duygusal emek ile işe bağlılık arasındaki ilişkide amir desteğinin rolü: Üniversitede öğrenci işleri personeline yönelik bir araştırma. Dokuz Eylül Üniversitesi iktisadi ve Idari Bilimler Fakültesi Dergisi, 28(2), 41-74.

Hochschild, A. R. (1983). The managed hearth: Commercialization of human feeling. Berkeley, CA: Univercity of California Pres.

Kalaycı, Ş. (2010). SPSS uygulamalı çok değişkenli istatistik teknikleri. Ankara: Asil Yayınları. 
Kaya, U., \& Özhan, Ç. K. (2012). Duygusal emek ve tükenmişlik ilişkisi: Turist rehberleri üzerine bir araştırma. Çalışma ilişkileri Dergisi, 3(2), 109-130.

Korkmaz, H., Sünnetçioğlu, S., \& Koyuncu, M. (2015). Duygusal emek davranışlarının tükenmişlik ve işten ayrılma niyeti ile ilişkisi: yiyecek içecek çalışanları üzerinde bir araştırma. Mehmet Akif Ersoy Üniversitesi Sosyal Bilimler Enstitüsü Dergisi, 7(12), 14-33.

Köksel, L. (2009). İş yaşamında duygusal emek ve ampirik bir çalışma. Celal Bayar Üniversitesi, Yayınlanmamış Yüksek Lisans Tezi, Manisa.

Kruml, I., \& Geddes, D. (2000). Exploring the dimensins of emotional labor:The heart of Hoschshild's work. Management Comunication Quarterly, 14(1), 8-49.

Leiter, M., \& Maslach, C. (1988). The ımpact of interpersonal environment on burnout and organizational commitment. Journal of Organizational Behavior, 9(4), 297-308.

Maslach, C. (2003). Job burnout: New directions in research and intervention. Current Directions in Psychological Science, 12(5), 189-192.

Maslach, C., \& Jackson, S. E. (1981). The measurement of experienced burnout. Journal of Occupational Behavior, 2, 99113.

Maslach, C., \& Zimbardo, P. (1982). Burnout the cost of caring. Englewood Cliffs, NJ: Prentice-Hall.

Maslach, C., Schaufeli W., B., \& Leiter M. P. (2001). Job burnout. Annual Review of Psychology, 52(1), 397-422.

Montgomery, A. J., Panagopolou, E., De Wildt, M., \& Meenks, E. (2006). Work-family interference, emotional labor and burnout. Journal of Managerial Psychology, 21(1), 36-51.

Morris, A., \& Feldman, D. (1996). The dimensions, antecedents, and consequences of emotional labor. Academy of Management Review, 21(4), 986-1010.

Oral, L., \& Köse, S. (2011). Hekimlerin duygusal emek kullanımı ile iş doyumu ve tükenmişlik düzeyleri arasındaki ilişkiler üzerine bir araştırma. Süleyman Demirel Üniversitesi iktisadi ve Idari Bilimler Fakültesi Dergisi, 16(2), 463-492.

Perlman, B., \& Hartman E. A. (1982). Burnout: Summary and future research. Human Relations, 35(4), 283-305.

PERYÖN Çalışan Devir Oranı Raporu, (2018). https://www.peryon.org.tr/uploads/2019/4/9/PERYÖN_Çalışan_Devir_Oranı_Sonuç_Raporu_2017-2018.pdf (Erişim Tarihi: 20 Şubat 2019).

Potter, B. (1998). Overcoming job burnout: How to renew enthusiasm for work (Second Ed.). Berkeley, CA: Ronin Publishing.

Rupp, D., Mccance, A., Spencer, S., \& Sonntag, K. (2008). Customer justice and emotional labor: The role of perspective taking, anger and emotional regulation. Journal of Management, 34(5), 903-924.

Schepman, S. B., \& Zorate, M. A. (2008). The relationship between burnout, negative affectivity and organizational citizenship behavior for human services employees. Engineering and Technology, 30, 437-441.

Sürgevil, O. (2005). Tükenmişlik ve tükenmişliği etkileyen örgütsel faktörler: Akademik personel üzerinde bir uygulama. Dokuz Eylül Üniversitesi, Yayınlanmamış Yüksek Lisans Tezi, İzmir.

Tak, B., \& Çiftçioğlu, B. (2008). Mesleki bağlılık ile çalışanların örgütte kalma niyeti arasındaki ilişkiyi incelemeye yönelik görgül bir çalışma. Ankara Üniversitesi SBF Dergisi, 63(4), 354-409.

Torun, A. (1997). Stres ve tükenmişlik. S. Tevrüz (Ed.), Endüstri ve örgüt psikolojisi. Türk Psikologlar Derneği ve Kalite Derneği Ortak Yayını.

Ural, A., \& Kılıç, İ. (2013). Bilimsel araştırma süreci ve SPSS ile veri analizi. Ankara: Detay Yayıncılık.

Üzümcü, T., \& Şahin, A. (2017). Konaklama işletmelerinde deneyimsel pazarlama ve duygusal emek. Kocaeli: Umuttepe Yayınları.

Waldroop, J., \& Butler, T. (2011). Çalışanları elde tutmak. Melis İnan (çev.). Istanbul: Optimist Yayınları.

Wharton, A. S. (1993). The affective consequences of service work managing emotions on the work. Work and Occupations, 20(2), 205-232.

Wright, T. A., \& Douglas, G. B. (1997). The contribution of burnout to work performance. Journal of Organizational Behavior, 18, 491-499.

Yang, F., \& Chang, C. (2008). Emotional labour, job satisfaction and organizational commitment among clinical nurses: A questionnaire survey. International Journal of Nursing Studies, 45, 879-887. 
Yang, J. (2008). Effect of new comersocialisation on organisational commitment, job satifaction and turnover intention in the hotel industry. The Service Industries Journal, 28(4), 429-443.

Yatkın, A. Y. (2007). William James'in Descartes'in duygu kuramına eleştirisi. Ankara Üniversitesi Dil ve Tarih-Coğrafya Fakültesi Felsefe Bölümü Dergisi, 18(1), 1-17.

Yeşil, S., \& Mavi, Y. (2018). Duygusal emeğin etkilediği faktörler üzerine bir alan araştırması. Aksaray Üniversitesi Iktisadi ve idari Bilimler Fakültesi Dergisi, 10(1), 29-44.

Yılmaz, K., Altınkurt, Y., Güner, M., \& Şen, B. (2015). The relationship between teachers' emotional labor and burnout level. Eurasian Journal of Educational Research, 59, 75-90.

Yürür, Ş., \& Ünlü, O. (2011). Duygusal emek, duygusal tükenme ve işten ayrılma niyeti ilişkisi. Işs, Güç Endüstri iliş̧kileri ve insan Kaynakları Dergisi, 13(2), 81-104.

Zhang, Q., \& Zhu, W. (2008). Exploring emotion in teaching: Emotional labor, burnout, and satisfaction in Chinese higher education. Communication Education, 57, 105-122. 
This Page Intentionally Left Blank 